\title{
Influence of Fertilizer Type on Beet Production and Post-Harvest Quality Characteristic
}

\author{
Carmen Rosa da Silva Curvêlo ${ }^{1}$, Layane Hyasmin Bernardes Diniz ${ }^{1}$, \\ Alexandre Igor de Azevedo Pereira1, Luiz Leonardo Ferreira ${ }^{2}$ \\ ${ }^{1}$ Goiano Federal Institute, Câmpus Urutaí, Urutaí, Brasil \\ ${ }^{2}$ University Center of Mineiros-UNIFIMES, Mineiros, Brasil \\ Email: carmencurvelo@yahoo.com.br,layane_hyasmin@hotmail.com, aiapereira@yahoo.com.br, luizleonardo@fimes.edu.br
}

How to cite this paper: Curvêlo, C.R. da S., Diniz, L.H.B., Pereira, A.I. de A. and Ferreira, L.L. (2018) Influence of Fertilizer Type on Beet Production and Post-Harvest Quality Characteristic. Agricultural Sciences, 9, 557-565.

https://doi.org/10.4236/as.2018.95038

Received: April 27, 2018

Accepted: May 25, 2018

Published: May 28, 2018

Copyright $\odot 2018$ by authors and Scientific Research Publishing Inc. This work is licensed under the Creative Commons Attribution International License (CC BY 4.0).

http://creativecommons.org/licenses/by/4.0/

\begin{abstract}
The beet (Beta vulgaris L.) vegetable is of great importance in the Brazilian market, mainly by having high nutritional values in consumer diet. Thus, the objective of this work was to evaluate the effects of organic and mineral fertilization on the production and post-harvest quality of beet. The experiment was conducted in the field, in the municipality of Urutaí-GO. The experimental design was a randomized block (DCB), where treatments were applied to two types of fertilizer: organic (chicken manure) and conventional (mineral fertilizer) with six replicates (using six tubers per plot). The following evaluations were made: horizontal and vertical diameters of the tubers $(\mathrm{cm})$ weight $(\mathrm{kg})$ Protein (g) Lipid (\%) Ash humidity (\%), electrical conductivity $\left(\mu \mathrm{S} \cdot \mathrm{cm}^{-1}\right)$, $\mathrm{pH}$, Titratable Acidity and Brix. The organic surpassed conventional treatment for all variables, except for the ash content, wherein the organic treating poultry litter base, showed $1.40 \%$ of ash and $\mathrm{pH}$ (6.48).
\end{abstract}

\section{Keywords}

Beta vulgaris L., Chicken Bed, Productivity

\section{Introduction}

Beetroot (Beta vulgaris L.) is a tuberose root crop belonging to the family Quenopodiáceae, considered one of the main crops grown in Brazil [1]. The main types of beet are horticultural beet, sugar beet and forage beet. In Brazil, beet cultivation was intensified with European and Asian immigration, being cultivated exclusively table varieties [2]. Currently, the cultivar Early Wonder is considered a traditional cultivar in the central-west region; because it has good adaptation in mild and cold temperatures, with cycle between 60 and 70 days, its 
booth can vary from 300 to 500 thousand plantas $\cdot \mathrm{ha}^{-1}$ [3].

The nutritional composition of table or horticultural beet stands out, among the vegetables, mainly because it presents high levels of antioxidant substances and sweetish flavor, pleasant to the palate of Brazilians and the forms of consumption [4] [5]. It also stands out as one of the richest vegetables in iron, both in roots and leaves [6]. According to [7] (Matos et al., 2012) beet is present in about 100 thousand rural properties in Brazil. Per year, it occupies an area equivalent to 10 thousand hectares, with a production of 300 thousand tons.

This tuberous root is quite nutritional demanding and has been cultivated in a traditional way, where its nutritional supply has been made through the use of mineral fertilizers. However, due to the high costs of these mineral fertilizers associated with soil and groundwater contamination problems, alternative ways have been sought to meet these needs [8].

According to [9] organic fertilization, especially with animal manure, appears as a great alternative, as it is highly beneficial to this crop, which has delicate and demanding roots regarding the physical aspect of the soil, besides helping to increase diversity biological [10].

The knowledge of the amount of nutrients accumulated in the plant, at each stage of development, provides important information that may aid in the crop fertilization program [11]. [12] evaluating post-harvest characteristics of beets submitted to different sources and doses of green manures verified a higher soluble solids content $\left(11.2^{\circ}\right.$ Brix) associated with Jitirana.

Thus, the objective of this work was to evaluate the effects of fertilizer types on post-harvest quality and on the production of beet of the Early Wonder bean in the municipality of Urutaí-GO.

\section{Material and Methods}

The experiment was conducted in the field of Urutaí-GO, during the period from October to December 2016, whose geographical coordinates of the municipality are $17^{\circ} 29^{\prime} 10^{\prime \prime} \mathrm{S}$ of latitude and $48^{\circ} 12^{\prime} 38^{\prime \prime} \mathrm{W}$ of longitude at $697 \mathrm{~m}$ altitude. The climate of the region is classified as tropical at altitude with dry winter and rainy summer, of type Cwb by classification of Köppen. The average annual temperature is $23^{\circ} \mathrm{C}$ in the period from September to October, reaching up to $30^{\circ} \mathrm{C}$ and between June and July, with a minimum of $15^{\circ} \mathrm{C}$. The mean annual rainfall is 1000 to $1500 \mathrm{~mm}$, with mean air relative humidity of $71 \%$. The soil of the experimental area was classified as Red Yellow Latosol, with a clay texture [13]. The results obtained in the soil chemical analysis, according to [14], in the layer $0-20 \mathrm{~cm}$ deep, before the installation of the experiment were: $\mathrm{pH} 4.80$; $23.2 \mathrm{~g} \cdot \mathrm{dm}^{-3}$ M.O. (Organic Matter); $6.1 \%$ CTC; base saturation of $42.3 \%$; 6.7 $\mathrm{mg} \cdot \mathrm{dm}^{-3}$ of $\mathrm{P} ; 3.50 \mathrm{cmolc} \cdot \mathrm{dm}^{-3} \mathrm{H}+\mathrm{Al} ; 0.2 \mathrm{cmolc} \cdot \mathrm{dm}^{-3}$ of $\mathrm{Al}^{3+} ; 0.37 \mathrm{cmolc} \cdot \mathrm{dm}^{-3}$ $\mathrm{K} ; 1.70 \mathrm{cmolc} \cdot \mathrm{dm}^{-3} \mathrm{Ca}^{2+}$ and $0.50 \mathrm{cmolc} \cdot \mathrm{dm}^{-3} \mathrm{Mg}^{2+}$.

The experimental design was randomized blocks (DBC) and the treatments corresponded to the application of two types of fertilization: organic (chicken 
bed) and conventional (mineral fertilizer) with six replications. The incorporation of the organic fertilizer to the soil was done 15 days before sowing.

The organic fertilizer used was based on chicken bed, being applied in the proportion of $2 \mathrm{~kg}$ per square meter of bed.

Mineral fertilization was carried out in two stages, $50 \%$ at planting and $50 \%$ at coverage with the NPK 20-5-20 mixture at 20 days after germination (DAG), as this was a longer cycle. Care was taken not to let the fertilizer have direct contact with the plants, not to cause burns or even to kill the beets. Thus, cover fertilization was applied around the plants in the beds. Before its application the control of the invasive plants was carried out and after its application an irrigation is carried out for a better absorption of the mineral fertilizer.

The beet cultivar used was cv. Early Wonder and its sowing were done directly in the beds, accommodating five seeds per pit, and manual thinning after emergence, around 15 days after sowing (DAS), leaving only one plant/pit, in beds of $1,0 \mathrm{~m}$ wide, $30.0 \mathrm{~m}$ long and $0.3 \mathrm{~m}$ high, and spaced $0.10 \mathrm{~m}$ between plants and $0.25 \mathrm{~m}$ between rows. The plots were of $2.0 \mathrm{~m}^{2}$, being evaluated the plants of the two central lines of the plots. Six tubers were used per plot, using the criterion of uniformity of size.

The plants were irrigated by the micro sprinkler method, during the whole conduction of the experiment and manual weeds were used to control weeds, besides the phytosanitary control of the beds whenever necessary.

After the harvest, the beets were cured at room temperature in the laboratory of General Chemistry of Campus Urutaí-IFGoiano and washed in running water in order to remove impurities from the field. The beets were then taken to the Organic Chemistry laboratory of the same campus for physical and chemical evaluations.

In the physical parameters, the fresh root mass per plot, diameter and root length were evaluated. To obtain the mass, a semi-analytical balance was used, expressing the values in grams (g), and for digital diameter and length the digital caliper was used, with results expressed in millimeters $(\mathrm{mm})$. From these, root mean mass and yield $\left(\mathrm{t} \cdot \mathrm{ha}^{-1}\right)$ were obtained, the latter being the product of the average mass by the number of plants per hectare.

For the post-harvest chemical evaluations of Beet, the following evaluations were carried out: Moisture Content, Ash Content, Soluble Solids (\%), Titratable Acidity (\%), pH, Lipid Content, Protein Content, Electrical Conductivity.

Moisture content was determined by the drying method, in an oven at $105^{\circ}$ for 24 hours, three weighings were carried out to the constant weight, by the methodology of the Adolfo Lutz Institute [15], Ash content was determined by the incineration principle of the sample in muffle at $550^{\circ} \mathrm{C}$ for four hours until the ashes are white or slightly grayish [15]. Soluble solids (\%) were determined by means of a digital refractometer from cellular juice extracted from $5 \mathrm{~g}$ of beet, using a four-sided drain. The titratable acidity (\%) was expressed as a percentage of citric acid equivalent to the amount of $0.1 \mathrm{~N} \mathrm{NaOH}$ spent in the titration us- 
ing $5 \mathrm{~mL}$ of juice, $50 \mathrm{~mL}$ of distilled water, using the phenolphthalein indicator until reaching the turning point, which is 8.2. [16]. The $\mathrm{pH}$ was obtained by the concentration of $\mathrm{H}^{+}$determined in the cellular juice using a digital $\mathrm{pH}$ meter, while the Electrical Conductivity $\left(\mu \mathrm{S} \cdot \mathrm{cm}^{-1}\right)$ was obtained by digital benchtop conductivity meter.

Lipid content was determined as ethereal extract by continuous extraction by the Soxhlet method using hexane as solvent according to [15]. The protein content was obtained by the Kjeldahl methodology, which determines the nitrogen contained in organic matter, and other non-protein nitrogenous compounds [15].

The results were analyzed with SAEG statistical software. When significant by means of the F test $(\mathrm{p}<0.05)$, the means were differentiated through the $\mathrm{F}$ test $(\mathrm{p}<0.05)$, and when the interaction was significant, the mean test was applied (Tukey, at a level of $5 \%$ probability).

\section{Results and Discussion}

In the treatments analyzed, significant differences were identified in relation to the vertical and horizontal diameters of the tubers (Table 1). Among the aspects of the post-harvest quality of beets of the Early Wonder bean evaluated, only Moisture, Ashes, $\mathrm{pH}$ and productivity, no significant differences were observed. Thus, significant differences between treatments were observed for the horizontal diameter of tubers (DHT), vertical diameter of tubers (DVT), fresh mass and productivity (Table 1). As in the electrical conductivity (EC), proteins, lipids ash content, moisture content, soluble solids and titratable acidity (Table 2).

Table 1. Physical parameters of beet plants submitted to two sources of fertilization. Campus Urutaí/IFGoiano, Urutaí-GO, 2017.

\begin{tabular}{ccccc}
\hline Tratamento & DHT (cm) & DVT (cm) & Massa (kg) & Prod. (t.ha $\left.{ }^{-1}\right)$ \\
\hline Conv. & $8.08^{\mathrm{a}}$ & $6.36^{\mathrm{a}}$ & $146.87^{\mathrm{a}}$ & $16.25^{\mathrm{a}}$ \\
Org. & $6.56^{\mathrm{b}}$ & $5.36^{\mathrm{b}}$ & $118.08^{\mathrm{b}}$ & $15.5^{\mathrm{a}}$ \\
\hline
\end{tabular}

Means followed by the same lowercase letter in the column do not differ from each other by the Tukey test at the $5 \%$ probability level. DHT $=$ Horizontal diameter of tubers; DVT $=$ Vertical diameter of tubers.

Table 2. Post-harvest quality chemical characteristics of beets submitted to two sources of fertilization. Campus Urutaí/IFGoiano, Urutaí-GO, 2017.

\begin{tabular}{ccccccccc}
\hline Trat. & $\begin{array}{c}\text { Proteínas } \\
(\mathrm{g})\end{array}$ & $\begin{array}{c}\text { Lipídeos } \\
(\%)\end{array}$ & $\begin{array}{c}\text { Umidade } \\
(\%)\end{array}$ & $\begin{array}{c}\text { Cinzas } \\
(\%)\end{array}$ & $\mathrm{CE}\left(\mu \mathrm{S} \cdot \mathrm{cm}^{-1}\right)$ & $\mathrm{pH}$ & $\mathrm{AT}(\%)$ & Brix \\
\hline Conv & $0.20^{\mathrm{a}}$ & $0.1^{\mathrm{a}}$ & $91.72^{\mathrm{a}}$ & $1.04^{\mathrm{a}}$ & $1351.83^{\mathrm{a}}$ & $6.12^{\mathrm{a}}$ & $1.05^{\mathrm{a}}$ & $6.33^{\mathrm{a}}$ \\
Org. & $0.20^{\mathrm{a}}$ & $0.1^{\mathrm{a}}$ & $93.86^{\mathrm{a}}$ & $1.40^{\mathrm{b}}$ & $815.56^{\mathrm{b}}$ & $6.48^{\mathrm{a}}$ & $0.33^{\mathrm{b}}$ & $3.00^{\mathrm{b}}$ \\
\hline
\end{tabular}

Means followed by the same lowercase letter in the column do not differ from each other by the Tukey test at the $5 \%$ probability level. $\mathrm{CE}=$ Electrical Conductivity; $\mathrm{AT}=$ Titratable Acidity. 
The horizontal length of the beet tubers was higher when treated in the conventional system than in the organic system, with a mean of $8.08 \pm 0.31 \mathrm{~cm}$ and $6.56 \pm 0.32 \mathrm{~cm}$, respectively $(\mathrm{F}=177.04, \mathrm{P}=0.00, \mathrm{gl}=5$ and $\mathrm{CV}=2.69)$ (Figure $1(\mathrm{a})$ ). While the vertical length of the tubers presented higher values

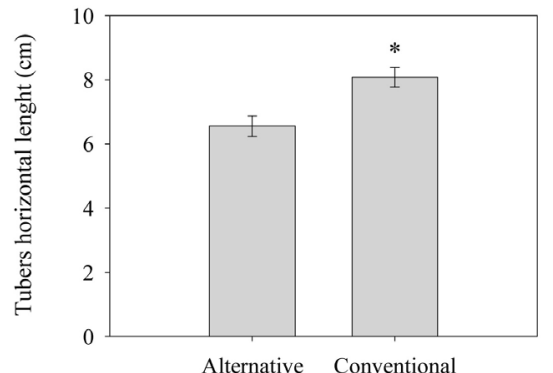

(a)

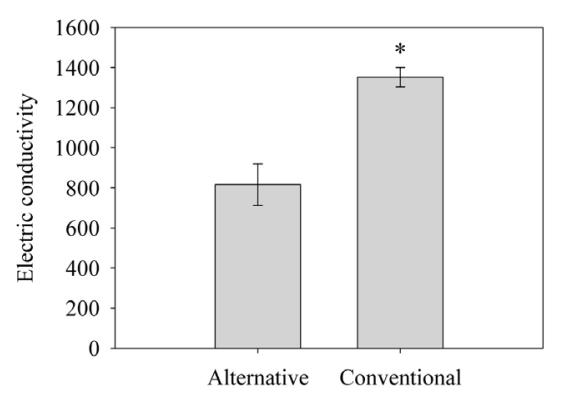

(c)

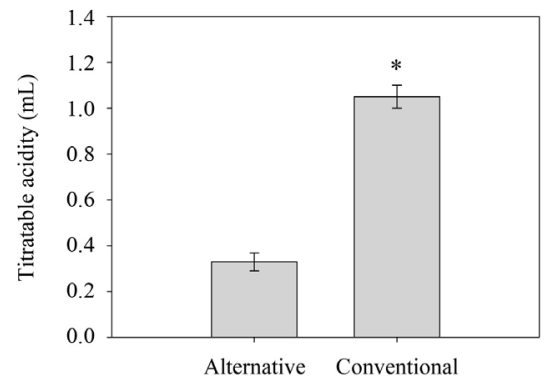

(e)

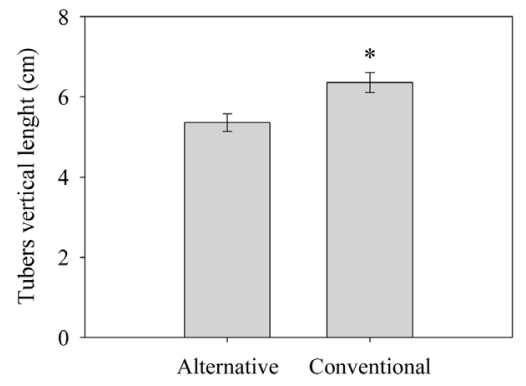

(b)

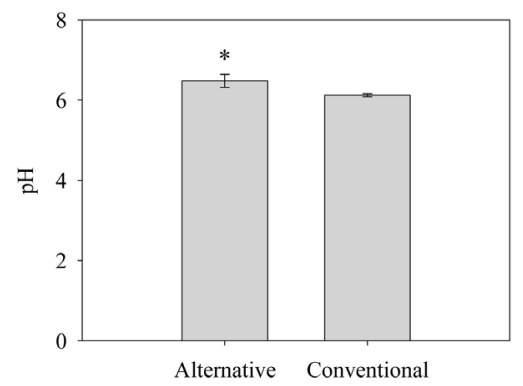

(d)

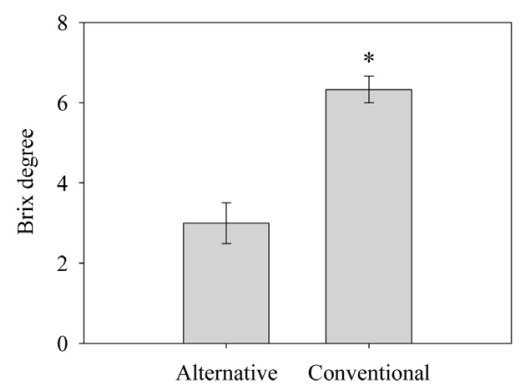

(f)

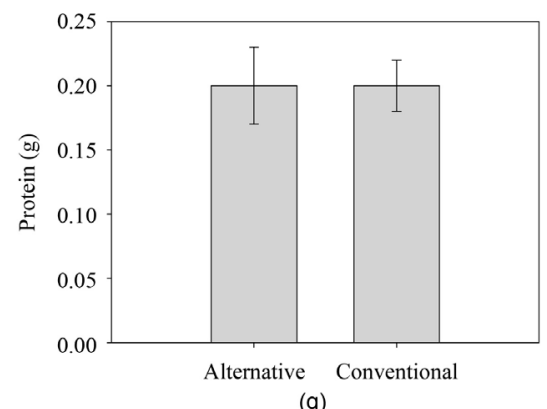

(g)

Figure 1. (a), tubers' vertical length $(\mathrm{cm})\left(\right.$ mean $\left.\pm \mathrm{SEM}^{*}\right)$ (b), electrical conductivity (mean $\pm \mathrm{SEM})(\mathrm{c}), \mathrm{pH}$ values (mean $\left.\pm \mathrm{SD}^{*}\right)(\mathrm{c})$, titratable acidity $\left(\right.$ mean $\left.\pm \mathrm{SEM}^{*}\right)(\mathrm{d})$, Brix (mean $\pm \mathrm{SEM}^{*}$ ) and protein content (Beta vulgaris $\mathrm{L}$.) cultivated under the organic or conventional system in the city of Urutaí, state of Goiás, Brazil. * Bars followed or not by an asterisk indicate a significant difference or non-significant similarity, respectively, at the level of $5 \%$ probability by the $\mathrm{F}$ test. 
when the beet plants were treated in the conventional system $(6.36 \pm 0.25 \mathrm{~cm})$ compared to the organic $(5.36 \pm 0.22 \mathrm{~cm})(\mathrm{F}=15,15, \mathrm{P}=0.01, \mathrm{gl}=5$ and $\mathrm{CV}=$ 7.58) (Figure 1(b)). [8] found close values working with beetroot cultivated in organic fertilization, where the increment of the doses of organic fertilizers provided non-significant responses in organic-mineral fertilization, however, the increase of the doses of aviary litter and manure in organic fertilization allowed diameters maximum of tubers, where it was estimated for the doses of 23.36 $\mathrm{t} \cdot \mathrm{ha} \mathrm{a}^{-1}$ of avian bed and $20.70 \mathrm{t} \cdot \mathrm{ha}^{-1}$ of bovine manure, the diameters of $46.79 \mathrm{~mm}$ and $40.33 \mathrm{~mm}$ transverse of tubers, respectively. In relation to the fresh mass of the tubers, it can be observed that the values $(118.08 \mathrm{~kg}$ and $146.87 \mathrm{~kg}$ ) for the treatments with the organic and mineral fertilizers, respectively, differed significantly. [17] evaluating the yield of beets as a function of nitrogen doses explain that the increase in root diameter is probably caused by the greater capacity of photosynthesis of the plants that received higher doses of $\mathrm{N}$, because plants submitted to such dosages presented greater mass fresh from the aerial part, probably caused by increases in the number and width of the leaves, culminating with the increase of its index of leaf area. In the present work, the liming performed in the conventional treatment (Commercial Fertilizer) probably provided the greatest availability of nutrients, and consequently favored the characteristics of diameters in comparison to the Organic (Chicken Bed) treatment, even though in the final productivity did not present significant effect.

[18] studying fertilization in beet consortium with lettuce obtained in the single beet cultivation with recommended conventional fertilization values of 6.8 $\mathrm{cm}$ diameters. The moisture content in the tubers was $91.72 \%$ for the treatment with mineral fertilizer and $93.86 \%$ for the treatment with organic fertilizer (Table 1). This feature is extremely important because it defines, in most cases of plant tissue, the level of hydration in which the tissue is found [19]. [20] evaluated the production and quality of tuberous roots of sweet potato cultivars in the western part of Paraná. The root moisture content of the cultivars was lower than the results found in this study, ranging from $66.18 \%$ to $75.86 \%$. Regarding ash content, there was a statistical difference between treatments, in which they were $1.04 \%$ Conventional and $1.40 \%$ Organic (Table 1). The ashes confer the amount of minerals present in the plant tissues.

[21] evaluating the post-harvest quality of beet submitted to fertilization with fermented biofertilizer, found values of ash between $1.05 \%$ and $1.19 \%$. The titratable acidity values were also strongly influenced by the beet culture system evaluated in the present study $(\mathrm{F}=142.23, \mathrm{P}=0.00, \mathrm{gl}=5$ and $\mathrm{CV}=15.04)$, and the conventional system yielded higher values of titratable acidity $(1.05 \pm 0.05$ $\mathrm{mL}$ ) compared to organic $(0.33 \pm 0.04 \mathrm{~mL})$ (Figure $1(\mathrm{e}))$. Similar results were found by [22], studying carrots grown under different sources and quantities of organic matter, did not find significant differences of titratable acidity. The $\mathrm{pH}$ value was the only variable quantified in the present study in which the value in the organic system exceeded that found in the conventional system $(\mathrm{F}=4.93, \mathrm{P}=$ 
$0.05, \mathrm{gl}=5$ and $\mathrm{CV}=4.49$ ) (Figure $1(\mathrm{~d})$ ). The $\mathrm{pH}$ means in the organic and conventional systems were $6.48 \pm 0.16$ and $6.12 \pm 0.04$, respectively (Figure 1(d), Table 2). The $\mathrm{pH}$ acts as an indicative of the taste of a vegetable, having an inverse relation to the acidity. However, the buffer capacity of some juices allows large variations in titratable acidity to occur, with no appreciable variations in $\mathrm{pH}[23]$ or $\mathrm{H}^{+}$concentration.

The electrical conductivity levels were higher in the conventional system $(1351.83 \pm 47.71)$ compared to the organic system $(815.56 \pm 103.96)(\mathrm{F}=16.29$, $\mathrm{P}=0.00, \mathrm{gl}=5$ and $\mathrm{CV}=21.23$ ) (Figure $1(\mathrm{c})$, Table 2). Concerning Brix, it was observed that the conventional system gave higher values in comparison to the organic system $(\mathrm{F}=62.50, \mathrm{P}=0.00, \mathrm{gl}=5$ and $\mathrm{CV}=15.64)$ with a mean of $6.33 \pm$ 0.33 (conventional) and $3.00 \pm 0.51$ (organic) (Figure 1(f)). [2] evaluating the production and quality of beet as a function of manure with bovine manure also verified that manure doses had no influence on soluble solids content (Brix).

Finally, the protein content quantified in the beet samples (Table 2) as a function of the different types of management (fertilization) of this plant was the only parameter that did not differ among the types of management evaluated $(\mathrm{F}=3.10, \mathrm{P}=0.13, \mathrm{gl}=5$ and $\mathrm{CV}=2.88)$. The protein means found were $0.20 \pm$ 0.02 and $0.20 \pm 0.03$ for the conventional and organic systems, respectively (Figure 1(g)). According to [24], which may contribute to a lower amount of protein during tuber formation, is the increase of the mean mass and accumulation of starch, which decreases the protein concentration (Table 2). [25] studying leaves, stalks, peels and seeds of plants: nutritional composition, use in feeding and sensorial analysis of preparations, verified protein and lipid contents of $1.88 \mathrm{~g}$ and $0.13 \mathrm{~g}$ respectively. According to the Brazilian Table of Food Composition-TACO, every 100 grams of raw beet the values of protein and lipids are $1.9 \mathrm{~g}$ and $0.1 \mathrm{~g}$ respectively [26].

\section{Conclusions}

Conventional treatment (mineral fertilization) stood out among the evaluated characteristics. Only the content of Ash and $\mathrm{pH}$ were influenced by the fertilization based on chicken litter (Organic Treatment). It is observed that the final productivity, even though it was not significant, there was an increase in the treatment with mineral fertilizer compared to fertilization with chicken litter.

Therefore, further in-depth studies on the quality of beet in isolated fertilizer sources are recommended.

\section{References}

[1] Tivelli, S.W., Factor, T.L., Teramoto, J.R.S., Fabri, E.G., Moraes, A.R.A., Trani, P.E. and May, A. (2011) Beterraba: Do plantio à comercialização. Instituto Agronômico (IAC), Boletim Técnico IAC, Campinas, 210, 1-45.

[2] Marques, L.F., Medeiros, D.C., Coutinho, O.L., Marques, L.F., Medeiros, C.B. and Vale, L.S. (2010) Produção e qualidade da beterraba em função da adubação com 
esterco bovino. Revista Brasileira de Agroecologia, 5, 24-31.

[3] Horticeres (2017) Beterraba Early Wonder Tall Top. http://www.horticeres.com.br/produtos/raizes-bulbos/beterraba/beterraba-early-wo nder-tall-top

[4] Aquino, L.A., Puiatti, M., Pereira, P.R.G., Pereira, F.H.F., Ladeira, I.R. and Castro, M.R.S. (2006) Produtividade, qualidade e estado nutricional da beterraba de mesa em função de doses de nitrogênio. Horticultura brasileira, 24, 199-203. https://doi.org/10.1590/S0102-05362006000200015

[5] Lacerda, Y.E.R. (2014) Produção e qualidade de cenouras e de beterrabas com aplicação de fertilizantes orgânicos. Dissertação (Mestrado), Universidade Estadual da Paraíba. Campina Grande, PB, 62 p.

[6] Sediyama, M.A.N., Santos, M.R., Vidigal, S.M. and Salgado, L.T (2011) Produtividade e exportação de nutrientes em beterraba cultivada com cobertura morta e adubação orgânica. Revista Brasileira Engenharia Agrícola Ambiental, 15, 883-889. https://doi.org/10.1590/S1415-43662011000900002

[7] Matos, F.A.C., Lopes, H.R.D., Dias, R.L. and Teixeira, R.A (2012) Beterraba: Saiba como cultivar hortaliças para colher bons negócios. Série Agricultura Familiar, 1-26. http://uc.sebrae.com.br/files/institutionalpublication/pdf/cartilha_beterraba_passo_ a_passo.pdf

[8] Pereira, A.L.S., Junior, O.P.M., Mendes, R.T., Neri, S.C.M., Pelá, G.M. and Pelá, A. (2010) Adubação orgânica e mineral na cultura da beterraba. In: VIII Seminário de Iniciação Científica e V Jornada de Pesquisa e Pós-Graduação, 8, Goiânia, Anais, $1-11$.

[9] Filgueira, A.R.F. (2008) Novo Manual de olericultura. $3^{\text {a }}$ Edition, Ed. UFV, Viçosa-SP.

[10] Magro, F.O (2012) Efeito do composto orgânico e adubação potássica em atributos do solo e da beterraba. Tese (Doutorado), Universidade Estadual Paulista "Júlio de Mesquita Filho", Botucatu, SP, 116 p.

[11] Grangeiro, L.C., Negreiros, M.Z., Souza, B.S., Azevêdo, P.E., Oliveira, S.L. and Medeiros, M.A. (2007) Acúmulo e exportação de nutrientes em beterraba. Ciências e Agrotecnologia, 31, 267-273. https://doi.org/10.1590/S1413-70542007000200001

[12] Batista, M.A.V., Neto, F.B., Aroucha, E.M.M., Ferreira, R.M.A., Sousa, C.M.G., Silva, M.L., Linhares, P.C.F., Bezerra, A.K.H. and Barros, G.L (2010) Características pós-colheita de beterraba submetida a diferentes fontes e doses de adubos verdes. Horticultura Brasileira, 28, 4110-4116.

[13] Embrapa. (1999) Sistema Brasileiro de Classificação de Solos. Centro Nacional de Pesquisa de Solos, Rio de Janeiro, RJ, 412 p.

[14] Raij, B., Andrade, J.C., Cantarella, H. and Quaggio, J.A. (2001) Análise química para avaliação da fertilidade de solos tropicais. SP, Instituto Agronômico de Campinas, Campinas, $285 \mathrm{p}$.

[15] IAL-Instituto Adolfo Lutz (2008) Métodos Físico-Químicos para Análise de Alimentos. $4^{\mathrm{a}}$ Edition, Ed. Digital, São Paulo-SP, 1020 p.

[16] Ryan, J.J. and Dupont, J.A. (1973) Identification and Analysis of the Major Acids from Fruit Juices and Wines. Journal Agricultural and Food Chemistry, 21, 45-49. https://doi.org/10.1021/jf60185a018

[17] Dasmaceno, L.A., Guimarães, M.A. and Guimarães, A.R. (2011) Produtividade de beterraba em função de doses de nitrogênio. Horticultura Brasileira, 29, 3694-3701. 
[18] Reis, J.M.R., Rodrigues, J.F. and Reis, M.A. (2013) Adubação em consórcio de beterraba com alface. Enciclopédia Biosfera, 9, 41-48.

[19] Albuquerque, J.R.T., Costa, F.B., Pereira, E.M., Rocha, T.C. and Lins, H.A. (2013) Qualidade Pós-Colheita da Cebola Roxa Produzida no Sertão Paraibano. Revista Verde de Agroecologia e Desenvolvimento Sustentável, 8, 17-22.

[20] Roesler, P.V.S.O., Gomes, S.D., Moro, E., Kummer, A.C.B. and Cereda, M.P. (2008) Produção e qualidade de raiz tuberosa de cultivares de batata-de batata-doce no oeste do este do este do Paraná. Acta Scientiarum Agronomy, 30, 117-122.

[21] Albuquerque, J.R.T., Formiga, A.S., Rocha, T.C., Costa, F.B. and Gondim, A.R.O. (2015) Qualidade pós-colheita de beterraba submetida à adubação com biofertilizantes fermentado. Revista Verde, 10, 41-46. https://doi.org/10.18378/rvads.v10i3.3652

[22] Moretti, C.L., Berg, F.L.N. and Mattos, L.M. (2003) Caracterização pós-colheita de cenouras cultivadas em sistema orgânico. Horticultura Brasileira, 21, 2.

[23] Chitarra, M.I.F. and Chitarra, A.B. (2005) Pós-colheita e frutos e hortaliças: Fisiologia e manuseio. UFLA: ESAL/FAEPE, 785 p.

[24] Belanger, G.R., Walsh, J.R., Richards, J.E., Milburn, P.H. and Ziadi, N. (2002) Nitrogen Fertilization and Irrigation Affects Tuber Characteristics of Two Potato Cultivars. American Journal of Potato Research, 79, 269-279.

https://doi.org/10.1007/BF02986360

[25] Storckl, C.R., Nunes, G.L., Oliveira, B.B. and Bassol, C. (2013) Folhas, talos, cascas e sementes de vegetais: Composição nutricional, aproveitamento na alimentação e análise sensorial de preparações. Ciência Rural, 43, 537-543.

https://doi.org/10.1590/S0103-84782013000300027

[26] Lima, D.M., Padovani, R.M., Amaya, D.B.R., Farfán, J.A., Nonato, C.T. and LIMA, M.T. (2011) Tabela Brasileira de Composição de Alimentos-TACO. 4th Edition, NEPA-UNICAMP, $161 \mathrm{p}$. http://www.unicamp.br/nepa/taco/contar/taco_4_edicao_ampliada_e_revisada 